\title{
Container Wall Porosity and Root Pruning Influence on Swietenia mahogani Root Ball Architecture and Anchorage After Planting
}

\author{
Edward F. Gilman, Maria Paz, and Chris Harchick
}

\begin{abstract}
Swietenia mahogani L. ability to anchor after planting in $9.5 \mathrm{~L}$ nursery containers has been attributed to root architecture within the original planted root ball. Objectives of this study were to evaluate root architecture, growth, and anchorage on trees planted from $57 \mathrm{~L}$ containers. Trunk diameter and tree height in nursery and after landscape planting were unaffected by propagation or nursery container type or root pruning at planting. Trees grown in solid-walled containers at every stage in the nursery had the greatest root defects. Unlike propagation containers, the wall porosity of the larger nursery container impacted root architecture eight months after planting to the landscape. A nursery container with porous walls produced a root system with fewer circling roots, more horizontal (straight) lateral roots, and greater root cross-sectional area bridging the container substrate/landscape soil interface than one with a solid wall. Root pruning (shaving or boxing) increased root system symmetry while reducing the $57 \mathrm{~L}$ visual rating of root deflection by the container. Despite improved root architecture, there was no impact of any treatment on anchorage (trunk tilt during winching or rest angle following winching) eight months after planting perhaps due to the short duration of the study.

Key Words. Air Root Pruning; Boxing; Mechanical Root Pruning; Nursery Container; Propagation Container; Shaving; Straight Roots; Swietenia mahogani.
\end{abstract}

Quality indices have been developed and refined for the more than 1.5 billion seedlings produced annually as part of reforestation efforts in the United States (Davis and Jacobs 2004). Some indices are physiologically based, others morphologically based. Large root volume, high root fibrosity, and a large number of first-order lateral roots have been correlated with improved field growth (Davis and Jacobs 2004); however, the herringbone or ladder-like root structure-which has many horizontal primary roots from the tap root and few secondary branches from primaries-is recognized as superior to other forms (Chapman and Colombo 2006). Lyford (1980) and others found herringbone-like architecture was the norm on naturally regenerated seedlings of several taxa. Containers producing seedlings with symmetrical herringbone-like root systems are therefore desirable because trees become more stable after planting (Burdett et al. 1986; Rune 2003).

The vertical orientation of structural roots induced by propagation containers-which differs from the largely horizontal orientation in many natural seedlings (Lindström and Rune 1999)—can be a serious deficiency in container-grown trees used in reforestation (Chavasse 1978; Wenny et al. 1988; Balisky et al. 1995). Storage of resources below ground is restricted by blocked translocation from entanglement of vertical structural roots (Graham and Bormann 1966; Hay and Woods 1968; Hay and Woods 1978). Producing forestry liners with horizontal roots growing from the top of the propagation container is feasible and practical (Wenny and Woollen 1989; Dumroese and Wenny 1997). For example, Chapman and Columbo (2006) showed that coating propagation containers with copper or growing in a substrate held together by fabric mesh produced herringbone root architecture that resulted in greater stability after planting, compared to containers that deflect roots vertically.

Despite advances in the forestry seedling profession in the last few decades, the landscape nursery industry has barely begun implementing or even 
studying the more complicated issues of growing much larger trees in field and container nurseries. Evaluating and growing high-quality trees for landscape markets may be more complex because instead of germinating in a seed bed or propagation container from which they are field planted, trees are typically moved from one field to another (Hewitt and Watson 2009) or they are shifted into larger containers up to four or five times during the course of production. Root architecture imposed by nursery practices in a landscape nursery can impact anchorage in the landscape (Gilman and Harchick 2014).

Trees with some large diameter, straight roots close to the soil surface often become well anchored in shallow (Coutts et al. 1990) and deep soils (Gilman and Wiese 2012), compelling development of field and container nursery trees with some large straight roots close to the surface of the root ball. Roots on established trees often proliferate close to the surface in soil with low oxygen content typical in disturbed urban zones (Watson and Kupkowski 1991). These can elongate from existing short roots within the root ball, from cut roots at the top portion of the root ball, or adventitiously from the root collar; however, certain nursery production systems induce a vertical root architecture (Hewitt and Watson 2009; Gilman and Paz 2014) that seems counterintuitive.

Some attempts have been made to standardize nursery tree quality. Florida Grades and Standards for Nursery Plants (Anonymous 2015) includes a formula for evaluating roots that circle the interior and/or periphery of the root ball. Specification Guidelines for Container-grown Trees in California (Anonymous 2009) states that there should be no circling roots on the periphery. The American Standard for Nursery Stock (Anonymous 2014) excludes soil over the root ball as part of the root ball depth measurement. Despite these advances, more detail than those provided by these sources may be necessary to describe the ideal nursery root system.

Anchorage after planting a common shade tree in tropical regions (Swietenia mahogani L., Gilman and Harchick 2014) from 9.5 L containers was attributable to root architecture within the original planted root ball (Gilman and Paz 2014). Objectives of the current study were to evaluate anchorage and root architecture on Swietenia mahogani planted from $57 \mathrm{~L}$ containers. Specifically tested was the influence of root architecture within the root ball imposed by growing trees in solid- and porous-walled containers on growth, root attributes, and anchorage, one growing season after landscape planting. Also tested was impact of removing-by pruning away-all roots growing on the root ball periphery at planting.

\section{MATERIALS AND METHODS}

\section{Growing Trees in the Nursery}

On February 11, 2009, in Loxahatchee, Florida U.S. (USDA hardiness zone 10a; mean low temperature $\left.-1^{\circ} \mathrm{C}\right)$, Swietenia mahogani seeds were placed into propagation (liner) containers in substrate consisting of $45 \%$ super-fine pine bark, $20 \%$ Florida peat, $10 \%$ horticultural perlite, $15 \%$ Allgro compost, and $10 \%$ coarse sand. The two propagation container types tested were 1) Bottomless Ellepot (EP) with sides constructed of paper $50 \mathrm{~mm}$ diameter $\times$ $90 \mathrm{~mm}$ tall, with a volume of $137 \mathrm{~cm}^{3}$ (Ellegaard, Esbjerg, Denmark; Ellepot paper made by Ahlstrom Stalldalen AB, Stalldalen, Sweden, from spruce, pine, and polyester long fibers, $27 \mathrm{~g} / \mathrm{m}^{2}, 190$ microns thick, $1320 \mathrm{~N} / \mathrm{m}$ dry tensile strength in machine direction, $2.0 \mathrm{~N}$ tear strength) arranged $10 \mathrm{~mm}$ apart in a plastic tray $(27 \mathrm{~cm} \times 53 \mathrm{~cm})$ exposing $100 \%$ of the paper sides to air and rested on an $8 \mathrm{~mm}$ wide plastic ring as part of the holder tray; and 2) a tray of smooth-sided (SM) black plastic containers 40 $\mathrm{mm}$ top diameter $\times 90 \mathrm{~mm}$ tall (volume $105 \mathrm{~cm}^{3}$ ) slightly tapered cone with a single drainage hole at the bottom. Trays (each with 40 to 55 containers) were arranged in a randomized fashion on wire mesh benches $80 \mathrm{~cm}$ from the ground in full sun in a non-climate controlled, open-sided greenhouse.

On July 27, 2009 (five months retention time in propagation container), trees were washed of substrate for root evaluation (described in Gilman and Paz 2014) or shifted into 3.8 L containers. One hundred liners of each propagation container type were shifted into either $3.8 \mathrm{~L}$ black plastic solid-walled smooth-sided slightly-tapered containers (SC1; 15.5 $\mathrm{cm}$ top diameter $\times 15.5 \mathrm{~cm}$ tall; Nursery Supplies, Inc., Chambersburg, Pennsylvania, U.S.) or into containers with exceptionally porous walls and bottom (Pioneer Pot; PC1; $19 \mathrm{~cm}$ top diameter $\times 17 \mathrm{~cm}$ tall, all container surfaces composed of approximately $15 \%$ plastic, $85 \%$ air including a bottom elevated $8 \mathrm{~cm}$ from ground, Pioneer Farms, Visalia, California, U.S.), and placed several $\mathrm{cm}$ apart on woven cloth on the ground 
in a randomized fashion. The sides of $\mathrm{PC} 1$ s were lined with paper (the same Ellepot paper described for propagation containers) to ensure substrate would not leach through the large (10 $\mathrm{mm}$ square) openings in the side. Substrate volume was equivalent in both 3.8 $\mathrm{L}$ containers; it reached the top in the PC1 containers and was $1 \mathrm{~cm}$ below the top in SM1 containers. The EP paper was not removed when shifting into $3.8 \mathrm{~L}$ containers. Controlled release fertilizer $\left(18 \mathrm{~N}-6 \mathrm{P}_{2} \mathrm{O}_{5}-\right.$ $12 \mathrm{~K}_{2} \mathrm{O}$, Nurserymen's Sure Gro, Vero Beach, Florida, U.S.) was surface applied to substrate (60\% pine bark: $30 \%$ Florida peat: $10 \%$ sand) following shifting to the $3.8 \mathrm{~L}$ container, and no other fertilizer was applied. Trees in $3.8 \mathrm{~L}$ containers were irrigated overhead typically two or three times daily in the growing season, less in the dormant season. Roots remained inside containers without rooting into the ground and without rooting into adjacent containers. Shoots were pruned once to maintain a dominant leader.

In January 2010 (six months retention time in 3.8 $\mathrm{L}$ containers), trees were either washed to measure roots (described in Gilman and Paz 2014), or shifted to $9.5 \mathrm{~L}$ containers of the same type (PC3 and SC3). Paper was not used to line the PC 3 because it did not appear to be needed to retain substrate. July 2010 trees (mean trunk diameter $15 \mathrm{~mm}$; tree height 1.1 $\mathrm{m}$ ) were shifted into $57 \mathrm{~L}$ solid-walled, smooth-sided black plastic round containers (44 cm top diameter $\times 35 \mathrm{~cm}$ height, Nursery Supplies Inc., Chambersburg, Pennsylvania, U.S.). The top of the root ball substrate was kept even with new substrate of the larger container at each shift, and no root manipulation was performed when shifting. In February 2012, eight trees from each propagation container type $x$ nursery container type combination (32 trees total) were washed of substrate to evaluate root systems in finished $57 \mathrm{~L}$ containers. Measurement details are described in the appropriate tables. Forty trees were planted into landscape soil from 57 L containers.

\section{Planting and Growing Trees in Land- scape Soil}

April 2012, 10 randomly chosen trees in $57 \mathrm{~L}$ containers of each of the four treatment combinations (two liners $\times$ two $3.8 \mathrm{~L}$ then $9.5 \mathrm{~L}$ containers $\times 10$ trees $=40$ trees) were planted into field soil [Millhopper fine sand (loamy, siliceous, hyperthermic Grossarenic Paleudults)] with less than 2\% organic matter) in Gainesville, Florida, U.S. (USDA hardi- ness zone $8 \mathrm{~b}$; mean low temperature $\left.-9^{\circ} \mathrm{C}\right)$. Trunk diameter $($ mean $=45 \mathrm{~mm}$ ) and tree height (mean $=2.6 \mathrm{~m}$ ) were recorded at planting and at harvest. The top of the root ball was positioned even with surrounding soil and trees were planted on a $0.9 \mathrm{~m}$ $\times 1.2 \mathrm{~m}$ grid. Some main roots emerged from the trunk base (root collar) within $1 \mathrm{~cm}$ of the substrate surface in conformance with Florida Grades and Standards for Nursery Plants (Anonymous 2015). Two trees from each treatment combination were randomly assigned to a block of eight trees for a total of five blocks; one was root pruned at planting and one not. Root pruning was performed by inserting a sharp square-tip balling spade into the root ball top surface tangent to the trunk, 3 to $6 \mathrm{~cm}$ inside the periphery, all the way to the bottom of the root ball once trees were planted and backfill was added (root ball took on a heptagon shape viewed from above).

Holes 10 to $15 \mathrm{~cm}$ wider than the root balls were hand dug with straight sides and flat bottoms and adjusted so the top of the undisturbed root ball was about even with the landscape soil surface. Bottom of holes were tamped by foot evenly around bottom of planting hole in an effort to standardize settling that might occur. Once the root ball was placed in the planting hole a $15 \mathrm{~cm}$ wide volume of undisturbed soil at the edge of hole was loosened and pushed into the hole. The rest was filled with soil that came out of the planting hole. Water was added to settle backfill soil, and soil was packed firmly with a person's foot. No berm or water ring was constructed around the root balls. A $10 \mathrm{~cm}$ thick layer of chipped branches and foliage from local utility pruning operations was placed across the entire plot almost up to the trunk with the intention of suppressing weeds.

A $60 \mathrm{~cm}$ diameter circular soil area around each tree was irrigated with $12 \mathrm{~L}$ through one Roberts spray stake (Model SS-AG160BLK-100) divided into three daily applications to encourage rapid growth. Fertilizer $\left(16 \mathrm{~N}, 0 \mathrm{P}_{2} 0_{5}, 8 \mathrm{~K}_{2} \mathrm{O} ; 270 \mathrm{~g}\right.$ in May and July 2012) was applied to a $60 \mathrm{~cm}$ diameter circular area around each tree. Glyphosate was applied as needed to supplement weed control. Shoots were not pruned at or after planting.

\section{Evaluating Anchorage and Roots}

October 30-31, 2012, all 40 trees were winched with a hand crank to evaluate lateral stability. Irrigation $(38 \mathrm{~L})$ was applied to a $0.75 \mathrm{~m}$ diameter circu- 
lar area centered on the trunk starting at 6:00 pm in the evening prior to pulling. No rain occurred during the two days required to pull trees. A force transducer (Model SSM-BYJ-50, $22.7 \mathrm{Kg}$, Interface, Scottsdale, Arizona, U.S., non-repeatability $- \pm 0.02 \% \mathrm{RO}$ ) was placed in line with a non-stretch cable that was secured around the tree with a tightened Zip tie at $20 \mathrm{~cm}$ from the ground. Trees were pulled at a rate of approximately $10 \mathrm{~mm} \cdot \mathrm{sec}^{-1}$ once due azimuth north to a bending stress $(\sigma)$ of 4.1 $\mathrm{MN} / \mathrm{m}^{2}$ calculated individually for each tree from trunk diameter measured $10 \mathrm{~cm}$ from the ground using equation 1 . This slow winching rate allowed researchers to stop pulling at the targeted bending stress. This bending stress was chosen so that the trunk nearly returned to the pre-pulling start angle following practice winching-indicating slight root or soil failure-on extra trees from the same group planted nearby. During winching tests, load was sampled at $2 \mathrm{~Hz}$ using a 16-bit data acquisition system (National Instruments Corporation, Austin, Texas, U.S.) and displayed and archived in realtime on the laptop running LabView software (v: 7.0; National Instruments, Austin, Texas, U.S.). Trunk angle was recorded just prior to each winching by placing a digital level $(18 \mathrm{~cm}$ long, M-D SmartTool Angle Sensor Module 92346) accurate to the tenth of a degree on the bottom $18 \mathrm{~cm}$ of trunk on the side opposite the crank (windward). A second winching applied a bending stress of $8.2 \mathrm{MN} / \mathrm{m}^{2}$. With the tree held in position by the winching cable, the angle under tension and the rest angle following release of the winching cable were recorded. The pre-winching trunk angle was subtracted from these angles to calculate change in angle as a result of winching.

[Equation 1] $\quad \sigma=\frac{F \cdot d \cdot R}{\frac{\pi}{4} \cdot R^{4}}$

where,

$\sigma=$ bending stress

$\mathrm{F}=$ pulling force

$\mathrm{d}=$ distance from pulling point to inclinometer

$\mathrm{R}=$ trunk radius (calculated as halving diameter measured with a diameter tape)

All 40 trees were excavated in December 2012 following winching, using a square-tipped shovel, forming a circular root ball $60 \mathrm{~cm}$ across and $60 \mathrm{~cm}$ deep, shaped in a cone typical of a tree dug from a field nursery. This shape and volume was large enough to harvest the planted $57 \mathrm{~L}$ container root ball intact. Soil and container substrate were washed from the whole root ball. Roots were measured for many attributes described in the appropriate tables. Root diameter was measured to $0.1 \mathrm{~mm}$.

\section{Statistical Analysis}

Data were analyzed in a randomized complete block design with one tree from each propagation container type $(2) \times$ nursery container type $(2) \times$ root pruning at landscape planting (2) combination in each of five blocks totaling 40 trees. Three-way analysis of variance in the GLM procedure within SAS (SAS Institute, Cary, North Carolina, U.S.) was used to evaluate impact of main effects and interactions on measured parameters. The three main effects were propagation container type, nursery container type, and root pruning at landscape planting. Means of main effects were separated with Duncan's multiple range test; interaction means were separated with LSD. Pearson's correlation coefficient was used to make correlations between root attributes and bending stress. Significant results were reported at $P<0.05$ unless indicated.

\section{RESULTS AND DISCUSSION}

Trunk diameter and tree height growth in the nursery and after planting to the landscape were not affected by propagation or nursery container type or root pruning at landscape planting, and there were no interactions (data not shown). Nursery container main effect was highly significant for many measured root attributes of finished trees in 57 L containers (Table 1). As found on Swietenia mahogani grown in $9.5 \mathrm{~L}$ containers (Gilman and Paz 2014), trees in PC developed a higher-quality root system (as defined in Anonymous 2009 and Anonymous 2015) than trees in SC. Specifically, root system imprint left by the propagation container (liner) and the 3.8 and $9.5 \mathrm{~L}$ containers, percent root ball circumference without roots, occurrence of culls due to circling roots, and percent trunk circled inside the $57 \mathrm{~L}$ container periphery were all smaller in PC containers by about half or more than trees in SC. Attributes associated with high quality had larger values for trees grown in PC than in SC. These values included radial root sym- 
metry, number of radiating straight roots, and percent of the five largest roots that grew straight from the root collar to the $57 \mathrm{~L}$ container wall (Table 1).

No measured root attribute inside $57 \mathrm{~L}$ container root ball was consistently affected by propagation container type without interacting with nursery container type. Although there were statistically significant differences between trees grown in EP and those in SM propagation containers for each nursery container, differences were small in comparison to differences between nursery container types (Table 2). Root balls of trees in PC containers had a smaller portion of root collar circumference lacking roots $>5 \mathrm{~mm}$ diameter, and five to eleven times the percentage of roots growing straight to the $57 \mathrm{~L}$ wall compared to trees in SC (Table 2). Others have also found a more symmetrical root system and large reductions in percent trunk circled with roots resulting from growing trees in porous-walled containers (Marshall and Gilman 1998, in Florida, U.S.; Owen and Stoven 2008, in Oregon, U.S.; Neal 2009, in New Hampshire, U.S.; Amoroso et al. 2010, in Italy; Stoven O'Conner et al. 2013, in Colorado, U.S.).

Fewer Swietenia mahogani roots were deflected by the EP compared to SM propagation container when measured in finished 3.8 L nursery containers (Gilman and Paz 2014). Specifically, root circling on finished trees grown for six months was cut 15 -fold and liner imprint was cut in half as a result of growing in EP versus SM propagation containers. Root circling was reduced to a five-fold difference and there was no impact on propagation container imprint rating when held in $3.8 \mathrm{~L}$ nursery containers 13 months (Gilman and Paz 2014). Percentage trunk circled at the propagation container position on finished trees in $9.5 \mathrm{~L}$ containers depended on the 3.8 and $9.5 \mathrm{~L}$ nursery container wall attributes (Gilman and Paz 2014); specifically, there was no EP-induced reduction in circling when trees were grown in SC nursery containers, but there was a

Table 1. Effect of nursery container type on root attributes in finished $57 \mathrm{~L}$ solid-walled containers.

\begin{tabular}{|c|c|c|c|c|c|}
\hline Nursery container $^{2}$ & $\begin{array}{l}\text { Liner visual } \\
\text { imprint rating }\end{array}$ & $\begin{array}{l}3.8 \mathrm{~L} \text { visual } \\
\text { imprint rating }\end{array}$ & $\begin{array}{l}9.5 \mathrm{~L} \text { visual } \\
\text { imprint rating }\end{array}$ & $\begin{array}{l}\% \text { root ball circumference } \\
\text { without roots }^{\mathrm{x}}\end{array}$ & $\%$ root cull ${ }^{\mathrm{w}}$ \\
\hline PC & $1.1 \mathrm{~b}^{\mathrm{s}}$ & $1.7 \mathrm{~b}$ & $2.2 \mathrm{~b}$ & $23 \mathrm{~b}$ & $7 \mathrm{~b}$ \\
\hline SC & $2.9 \mathrm{a}$ & $4.4 \mathrm{a}$ & $4.2 \mathrm{a}$ & $66 \mathrm{a}$ & $64 \mathrm{a}$ \\
\hline Nursery container & $\begin{array}{l}\% \text { trunk circled inside } \\
57 \text { L periphery }^{\mathrm{v}}\end{array}$ & $\begin{array}{l}\text { Radial root ball } \\
\text { symmetry }^{\mathrm{u}}\end{array}$ & \multicolumn{2}{|c|}{$\begin{array}{l}\text { No. radiating straight roots } \\
\text { to periphery of } 57 \mathrm{~L} \text { container }\end{array}$} & $\begin{array}{l}\% \text { five largest roots } \\
\text { grew straight }\end{array}$ \\
\hline PC & $22 \mathrm{~b}$ & $4.3 \mathrm{a}$ & \multirow{2}{*}{\multicolumn{2}{|c|}{$\begin{array}{l}12 \mathrm{a} \\
3 \mathrm{~b}\end{array}$}} & $65 \mathrm{a}$ \\
\hline SC & $65 \mathrm{a}$ & $2.1 \mathrm{~b}$ & & & $9 \mathrm{~b}$ \\
\hline
\end{tabular}

${ }^{\mathrm{z}}$ Trees grown in either porous- (PC) or solid-walled (SC) $3.8 \mathrm{~L}$ then $9.5 \mathrm{~L}$ nursery containers prior to shifting into $57 \mathrm{~L}$ solid-walled containers.

y Visual rating of root deflection severity at indicated container position with $1=$ little imprint or retained "cage" formed by deflected roots, and $5=$ strong imprint formed by deflected roots retaining the shape of the container.

${ }^{\mathrm{x}}$ Percentage circumference (looking down on the root ball) lacking roots $>5 \mathrm{~mm}$ diameter.

" According to Florida Grades and Standards for Nursery Plants (Anonymous 2015).

vercent trunk circled with roots $>3 \mathrm{~mm}$ diameter from liner, 3.8 , and/or 9.5 position.

"Visual rating with 1 = radially asymmetrical distribution of roots with most on one side of root ball, and $5=$ radially symmetrical distribution of mother roots (roots growing directly from stem).

${ }^{\mathrm{t}}$ Number of roots $>3 \mathrm{~mm}$ diameter measured just inside the $57 \mathrm{~L}$ container wall that grew from trunk at $<45$ degree angle to substrate surface without making a turn of $>60$ degrees relative to parent root azimuth at trunk; root diameter measured at trunk.

${ }^{s}$ Means in a column with a different letter are statistically different at $P<0.0004 ; \mathrm{n}=16$ trees averaged across propagation container type due to insignificant interaction with propagation container type.

Table 2. Effect of propagation and nursery container type on root attributes in finished $57 \mathrm{~L}$ solid-walled containers.

\begin{tabular}{llll}
\hline $\begin{array}{l}\text { Propagation container } \\
(\text { liner })^{\mathrm{z}}\end{array}$ & $\begin{array}{l}\text { Nursery } \\
\text { container }\end{array}$ & $\begin{array}{l}\text { \% circumference } \\
\text { without roots }^{\mathrm{x}}\end{array}$ & $\begin{array}{l}\text { \% five largest roots } \\
\text { grew straight }\end{array}$ \\
\hline EP & PC & $21 \mathrm{c}^{\mathrm{v}}$ & $69 \mathrm{a}$ \\
& SC & $70 \mathrm{a}$ & $6 \mathrm{~d}$ \\
SM & PC & $24 \mathrm{c}$ & $62 \mathrm{~b}$ \\
& SC & $62 \mathrm{~b}$ & $12 \mathrm{c}$ \\
\hline
\end{tabular}

${ }^{z}$ Trees seeded into either Ellepot (EP) or smooth-sided (SM) container before shifting to 3.8 L nursery container.

${ }^{y}$ Trees grown in either porous- (PC) or solid-walled (SC) $3.8 \mathrm{~L}$ then $9.5 \mathrm{~L}$ nursery containers prior to shifting into $57 \mathrm{~L}$ solid-walled containers.

${ }^{x}$ Percentage of root ball circumference, looking down on the root ball, lacking roots $>3 \mathrm{~mm}$ diameter.

${ }^{w}$ Percent of roots that grew from trunk to $5 \mathrm{~cm}$ inside $57 \mathrm{~L}$ container wall position at $<45$ degree angle to substrate surface without making a turn of $>60$ degrees relative to parent root azimuth at trunk; root diameter measured at trunk.

${ }^{v}$ Means in a column with a different letter are statistically different at $P<0.04$ and 0.0001 , left to right; $\mathrm{n}=8$. 
13-fold reduction for trees grown in PC containers. PC nursery container appeared to induce a shift in root growth in $9.5 \mathrm{~L}$ containers from existing verti$\mathrm{cal}$ and circling roots to more lateral straight roots oriented horizontally when propagated in EP. The current study showed that by the time Swietenia mahogani trees had finished in $57 \mathrm{~L}$ nursery containers, propagation container had no main effect (across both nursery containers) on percent trunk circled with roots $>3 \mathrm{~mm}$ diameter or liner imprint rating (data not shown); the same was true for trees seven months after planting $57 \mathrm{~L}$ containers into the landscape. This suggests that although circling and deflected roots at the propagation liner position represented an important part of the root system on trees in 3.8 and $9.5 \mathrm{~L}$ containers (Gilman and Paz 2014), most of them did not become larger than $3 \mathrm{~mm}$ diameter more than two years later.

Propagation container interacted with nursery container type for root attributes measured eight months after landscape planting. Trees grown in solid-walled containers at every stage in the nursery had the most defects. Specifically, those propagated in SM and shifted to SC had fewer radiating straight roots (three or four), a smaller percentage of the largest five roots grew into landscape soil (18\%), and they had a much larger percentage $(78 \%)$ of $57 \mathrm{~L}$ root ball circumference circled with roots compared to those in the other three combinations of propagation and nursery containers (Table 3 ). Given the similar size of trees among treatments, fewer radiating structural roots implied more vertical roots, measured on younger mahogany (Gilman and Paz 2014). Trees from EP propagation containers had higher values for three root attributes associated with better quality root systems and a smaller percentage trunk circled with roots $>5 \mathrm{~mm}$ diameter than trees propagated in SM but only when shifted into SC nursery containers (Table 3). In contrast, propagation type had no impact on trees shifted into PC nursery containers. Shifting trees propagated in SM containers into PC nursery containers increased number of radiating roots and percentage of the largest roots growing into landscape soil to the point of matching that of trees propagated in EP shifted into PC. The air pruning occurring under the 3.8 and 9.5 L nursery containers slowed or aborted root elongation along the container bottom, which apparently forced more roots to emerge from the root collar.
Some of these roots grew horizontally, resulting in more straight roots radiating from the trunk base (Table 3 ). These results suggest that at least some of the negative attributes of a solid-walled propagation container could be overcome by transferring liners to a highly porous-walled (PC) nursery container.

Roots grew through the porous walls of $\mathrm{PC}$ at night and then turned brown (observation not measured) in the daylight hours the following day. This phenomenon was also evident on trees finished in 3.8 and $9.5 \mathrm{~L}$ containers, and it induced horizontal, lateral root architecture that was evident up to eight months after landscape planting (Gilman and Harchick 2014). The high humidity at night allowed roots to elongate into the atmosphere outside the substrate but root tips soon died back after dawn as humidity dropped and the sun struck white root tips. Roots burning back on the underside of the container (the $8 \mathrm{~cm}$ elevated bottom) restricted growth of vertically oriented roots and likely initiated lateral roots as Salonius et al. (2000) and others have found. This would explain why lateral roots were able to dominate and become larger than vertical and circling roots at the bottom of containers. Although there are many plastic container types with holes on the periphery and bottom, the amount of porosity and distribution and shape of holes required to elicit this response have not been determined. In contrast, roots striking the bottom of SC containers-and perhaps other containers with a low porosity bottom-continue growing along the bottom, likely due to adequate supply of moisture and nutrients.

Nursery container type also influenced root architecture inside the root ball and in landscape soil without interacting with propagation container type. Trees in PC had far less of a visual root imprint from the 3.8 and 9.5 L nursery containers, and much less of the trunk was circled with roots than trees in SC (Table 4). Nearly double the number of roots $>3 \mathrm{~mm}$ diameter grew straight to the edge of the $57 \mathrm{~L}$ container root ball (nine versus five), and about double the percent of the five largest roots grew into landscape soil, when planting from PC compared to SC. Root mass within a $60 \mathrm{~cm}$ wide and deep cone-shaped excavated root ball was less for trees grown in PC than SC. Less mass may have been due to the air pruning occurring at the PC nursery container periphery, causing a branching instead of 
enlargement of woody, structural roots. Others noted that the number of root tips increased in response to mechanical blockage or air pruning (Whitcomb and Williams 1985; Krasowski and Owens 2000). Arnold and Young (1991) and Gilman and Beeson (1995) also showed that there was a reduction in root mass from growing trees in copper coated containers, which reduced container imprint by chemically pruning root tips.

Like nursery container type, root pruning by shaving the $57 \mathrm{~L}$ root ball periphery at planting dramatically influenced root architecture eight months later. Values of attributes often assigned to poor root systems, including imprinting, circling, and asymmetry declined by a factor of three to sixteen as a result of root pruning at planting (Table 5, first four columns). Attributes associated with higher quality root systems increased in value with root pruning, including symmetry, number of radiating straight and large roots, and two measures of root cross-sectional area (CSA) growing into landscape soil. Root pruning nearly doubled the ratio of root CSA growing from the top compared to the bottom half of the root ball, which has been associated with improved anchorage on seedlings (Wenny and Woollen 1989; Dumroese and Wenny 1997). Others found root architecture and slight anchorage improvements from shaving $57 \mathrm{~L}$ (Weicherding et al. 2007; Gilman and Weise 2012) and 246 L (Gilman 2013) root balls when landscape planting.

Mechanical root pruning at planting interacted with nursery container type for three measured parameters. Trees grown in SC and root pruned at landscape planting had a smaller portion $(54 \%$,

Table 3. Effect of propagation and nursery container type on root attributes eight months after planting $57 \mathrm{~L}$ container root ball into landscape soil.

\begin{tabular}{|c|c|c|c|c|c|}
\hline $\begin{array}{l}\text { Propagation } \\
\text { container } \\
(\text { liner })^{z} \\
\end{array}$ & $\begin{array}{l}\text { Nursery container } \\
\text { type }^{z}\end{array}$ & $\begin{array}{l}\text { No. radiating straight } \\
\text { roots trunk to position } \\
\text { of } 57 \mathrm{~L} \text { container wall }{ }^{\mathrm{y}}\end{array}$ & $\begin{array}{l}\text { No. radiating straight } \\
\text { roots trunk to beyond } \\
57 \text { L position }^{x}\end{array}$ & $\begin{array}{l}\% \text { five largest roots } \\
\text { that grew into } \\
\text { soil }^{\mathrm{w}}\end{array}$ & $\begin{array}{l}\text { \% circumference circled } \\
\text { inside position of } 57 \mathrm{~L} \\
\text { container wall }^{\mathrm{v}}\end{array}$ \\
\hline \multirow[t]{2}{*}{$\mathrm{EP}$} & PC & $9 \mathrm{a}^{\mathrm{u}}$ & $11 \mathrm{a}$ & $54 \mathrm{a}$ & $20 c$ \\
\hline & SC & $6 b$ & $10 \mathrm{a}$ & $36 \mathrm{~b}$ & $47 \mathrm{~b}$ \\
\hline \multirow[t]{2}{*}{ SM } & PC & $9 \mathrm{a}$ & $13 \mathrm{a}$ & $56 \mathrm{a}$ & $15 \mathrm{~d}$ \\
\hline & SC & $3 c$ & $4 \mathrm{~b}$ & $18 \mathrm{c}$ & $78 \mathrm{a}$ \\
\hline
\end{tabular}

${ }^{z}$ Trees seeded into either Ellepot (EP) or smooth-sided container (SM) then into either porous- (PC) or solid-walled (SC) 3.8 L then 9.5 L nursery containers prior to shifting into $57 \mathrm{~L}$ solid-walled containers, then planted into landscape soil.

${ }^{y}$ Number of roots $>3 \mathrm{~mm}$ diameter measured $5 \mathrm{~cm}$ inside the position of the $57 \mathrm{~L}$ container wall that grew from trunk at $<45$ degree angle to substrate surface without making a turn of $>60$ degrees relative to parent root azimuth at trunk.

${ }^{x}$ Number of roots $>3 \mathrm{~mm}$ diameter measured $5 \mathrm{~cm}$ beyond the position of the $57 \mathrm{~L}$ container wall that grew from trunk at $<45$ degree angle to substrate surface without making a turn of $>60$ degrees relative to parent root azimuth at trunk.

w Percent of the five largest diameter roots (diameter measured just beyond root collar) that grew beyond the periphery of the $57 \mathrm{~L}$ container position following the largest root at forks.

${ }^{v}$ Percent trunk circumference circled with roots $>5 \mathrm{~mm}$ diameter from either propagation container, 3.8, and/or 9.5 L container position.

" Means in a column with a different letter are statistically different at $P<0.04 ; \mathrm{n}=10$, averaged across root pruning at landscape planting due to insignificant interactions.

Table 4. Effect of nursery container type on trunk diameter and root attributes eight months after planting $57 \mathrm{~L}$ container root ball into landscape soil.

\begin{tabular}{|c|c|c|c|c|c|c|c|}
\hline $\begin{array}{l}\text { Nursery } \\
\text { container }^{2}\end{array}$ & $\begin{array}{l}3.8 \mathrm{~L} \text { visual } \\
\text { imprint rating }\end{array}$ & $\begin{array}{l}9.5 \mathrm{~L} \text { visual } \\
\text { imprint rating }\end{array}$ & $\begin{array}{l}\% \text { trunk circled } \\
\text { inside } 57 \mathrm{~L} \text { wall } \\
\text { position }^{\mathrm{x}}\end{array}$ & $\begin{array}{l}\% \text { trunk circled at } \\
57 \text { L wall position }\end{array}$ & $\begin{array}{l}\text { No. radiating straight roots } \\
\text { trunk to position of } 57 \mathrm{~L} \\
\text { container wall }^{v}\end{array}$ & $\begin{array}{l}\% \text { five largest roots } \\
\text { grew into soil }{ }^{u}\end{array}$ & $\begin{array}{l}\text { Root dry } \\
\text { mass }(g)^{t}\end{array}$ \\
\hline PC & $1.6 b^{s}$ & $2.3 \mathrm{~b}$ & $18 \mathrm{~b}$ & $27 \mathrm{~b}$ & $9 \mathrm{a}$ & $55 \mathrm{a}$ & $1029 \mathrm{~b}$ \\
\hline SC & $4.3 \mathrm{a}$ & $4.3 \mathrm{a}$ & $62 \mathrm{a}$ & $34 \mathrm{a}$ & $5 \mathrm{~b}$ & $27 \mathrm{~b}$ & $1247 \mathrm{a}$ \\
\hline
\end{tabular}

${ }^{z}$ Trees grown in either porous- (PC) or solid-walled (SC) $3.8 \mathrm{~L}$ then $9.5 \mathrm{~L}$ nursery containers prior to shifting into $57 \mathrm{~L}$ solid-walled containers.

${ }^{y}$ Visual rating of root deflection severity at indicated container position with $1=$ little imprint or retained "cage" formed by deflected roots, and $5=$ strong imprint formed by deflected roots retaining the shape of the container.

${ }^{x}$ Percent trunk circumference circled with roots $>5 \mathrm{~mm}$ diameter from either propagation container, 3.8 , and/or $9.5 \mathrm{~L}$ container position.

w Percent trunk circled with roots $>5 \mathrm{~mm}$ diameter at the position of the periphery of the $57 \mathrm{~L}$ root ball.

${ }^{v}$ Number of roots $>3 \mathrm{~mm}$ diameter measured $5 \mathrm{~cm}$ inside the position of the $57 \mathrm{~L}$ container wall that grew from trunk at $<45$ degree angle to substrate surface without making a turn of $>60$ degrees relative to parent root azimuth at trunk.

${ }^{u}$ Percent of the five largest diameter roots (diameter measured just beyond root collar) that grew beyond the periphery of the $57 \mathrm{~L}$ container position following the largest root at forks.

${ }^{\mathrm{t}}$ All roots within a $60 \mathrm{~cm}$ diameter cone-shaped root ball $60 \mathrm{~cm}$ deep.

${ }^{s}$ Means in a column with a different letter are statistically different at $P<0.01 ; \mathrm{n}=20$, averaged across propagation container type and root pruning due to insignificant interactions. 
Table 6) of trunk circumference with circling roots than trees planted from SC without pruning (69\%). Root pruning also more than doubled the percentage ( $16 \%$ to $38 \%)$ of the five largest roots growing into landscape soil, suggesting that pruning shifted root growth from the container substrate to the landscape soil. In contrast, trees grown in PC and root pruned at planting developed more circling roots than those not pruned. In addition to generating new roots at the cut, root pruning is known to stimulate growth of existing roots proximal to the cut surface (Watson and Sydnor 1987); some of these air-pruning-induced lateral roots growing perpendicular to the cut on radially oriented mother roots evidently grew tangent to the trunk, resulting in an increase in circling roots. Despite this significant effect, trees grown in PC had a much smaller portion of trunk circled with roots $>5 \mathrm{~mm}$ diameter than those in SC, regardless of whether roots were pruned at planting (Table 6).

Root pruning at planting dramatically reduced percentage of root collar circumference lacking roots $>5 \mathrm{~mm}$ diameter for both nursery container types; i.e., root pruning induced better root system symmetry (Figure 1). Root pruning increased percent five largest roots growing into landscape soil more for PC (78\%) than for SC
(38\%) containers (Table 6). Many of the largest roots on SC trees were deflected by the smaller container sizes (3.8 and 9.5 L, Gilman and Paz 2014) so these would not have been cut when $57 \mathrm{~L}$ trees were shaved. Therefore, these roots remained deflected within the $57 \mathrm{~L}$ root ball volume without growing out into landscape soil (Figure 1). This may ultimately result in less landscape soil mass bound together into a root plate, which has been shown to reduce stability as trees grow (Danjon et al. 2005; Fourcaud et al. 2007).

Despite improved root architecture on trees grown in PC nursery containers and from mechanical root pruning at planting, there was no impact of any treatment on trunk tilt during winching or rest angle following winching. This might be explained by the brief time between planting and winching (seven months); many previous winching tests that evaluated stability were performed several or many years after planting. Perhaps the $20 \%$ greater mass of the imprinted SC root system close to the trunk (Table 4) also bound together more container substrate mass due to root stiffness than trees from PC containers. Despite less root mass on trees planted from PC containers, anchorage may have been comparable to those from SC due to improved root architecture; i.e.,

Table 5. Root attributes ${ }^{2}$ eight months after root pruning $57 \mathrm{~L}$ container root balls when planted into landscape soil.

\begin{tabular}{llllll}
\hline Root pruning $^{\mathrm{y}}$ & $\begin{array}{l}57 \mathrm{~L} \text { visual } \\
\text { imprint }^{\mathrm{x}}\end{array}$ & $\begin{array}{l}\text { \% circumference circled } \\
\text { at position of } 57 \mathrm{~L} \\
\text { container wall }\end{array}$ & $\begin{array}{l}\text { No. roots }>5 \mathrm{~mm} \\
\text { diameter deflected by } \\
57 \mathrm{~L} \text { container wall }\end{array}$ & $\begin{array}{l}\text { \% circumference without } \\
\text { roots }>5 \mathrm{~mm} \text { diameter } 5 \mathrm{~cm} \\
\text { beyond } 57 \mathrm{~L} \text { wall position }\end{array}$ & $\begin{array}{l}\text { Radial root ball } \\
\text { symmetry }\end{array}$ \\
\hline Yes & $1.5 \mathrm{~b}^{\mathrm{q}}$ & $4 \mathrm{~b}$ & $\begin{array}{l}\text { No. radiating } \\
\text { straight roots } \\
\text { trunk to } \\
\text { beyond } 57 \mathrm{~L} \\
\text { wall position }^{\mathrm{u}}\end{array}$ \\
No & $4.4 \mathrm{a}$ & $59 \mathrm{~b}$ & $\begin{array}{l}1 \mathrm{~b} \\
16 \mathrm{a}\end{array}$ & $\begin{array}{l}22 \mathrm{~b} \\
58 \mathrm{a}\end{array}$
\end{tabular}

Root pruning \% five largest roots Total no, roots grew from No. roots grew from top Total root CSA $\left(\mathrm{mm}^{2}\right)^{\mathrm{r}} \quad$ Ratio root CSA from grew into soil ${ }^{\mathrm{t}} \quad \begin{array}{lll}\text { entire } 57 \mathrm{~L} \mathrm{root} \mathrm{ball}^{\mathrm{s}} & \text { half of } 57 \mathrm{~L} \mathrm{root} \mathrm{ball}^{\mathrm{s}} & \text { top: bottom half of }\end{array}$

\begin{tabular}{lllll}
\hline Yes & $58 \mathrm{a}$ & $27 \mathrm{a}$ & $18 \mathrm{a}$ & $862 \mathrm{a}$ \\
No & $22 \mathrm{~b}$ & $12 \mathrm{~b}$ & $7 \mathrm{~b}$ & $2.3 \mathrm{a}$ \\
\end{tabular}

${ }^{\mathrm{z}}$ Root characteristics measured within a hand dug, shoved-excavated, cone-shaped soil volume $60 \mathrm{~cm}$ in diameter and $60 \mathrm{~cm}$ deep centered on the trunk.

${ }^{\mathrm{y}}$ Trees were root pruned by shaving away the outer 3 to $4 \mathrm{~cm}$ periphery of the $57 \mathrm{~L}$ root ball when planted into the landscape.

${ }^{x}$ Visual rating of root deflection severity at $57 \mathrm{~L}$ container position with $1=$ little imprint or retained "cage" formed by deflected roots, and $5=$ strong imprint formed by deflected roots retaining the shape of the container).

${ }^{w}$ Percent trunk circled with roots $>5 \mathrm{~mm}$ diameter at the position of the periphery of the $57 \mathrm{~L}$ root ball.

${ }^{v}$ Visual rating with $1=$ radially asymmetrical distribution of roots with most on one side of root ball, and $5=$ radially symmetrical distribution of mother roots (roots growing directly from stem).

u Number of roots $>3 \mathrm{~mm}$ diameter measured $5 \mathrm{~cm}$ beyond the position of the $57 \mathrm{~L}$ container wall that grew from trunk at $<45$ degree angle to substrate surface without making a turn of $>60$ degrees relative to parent root azimuth at trunk.

${ }^{t}$ Percent of the five largest diameter roots (diameter measured just beyond root collar) that grew beyond the periphery of the $57 \mathrm{~L}$ container position following the largest root at forks.

${ }^{\mathrm{s}}$ Roots $>3 \mathrm{~mm}$ diameter measured $5 \mathrm{~cm}$ beyond 57 L periphery.

${ }^{\mathrm{r}}$ Root cross-sectional area (CSA) measured $5 \mathrm{~cm}$ outside $57 \mathrm{~L}$ root ball position for roots $>3 \mathrm{~mm}$ diameter growing from entire root ball periphery.

${ }^{\mathrm{q}}$ Means in a column with a different letter are statistically different at $\mathrm{P}<0.0002 ; \mathrm{n}=20$, averaged across propagation and nursery container types due to insignificant interactions. 
Table 6. Effect of nursery container type and root pruning at landscape planting on root attributes eight months later.

\begin{tabular}{|c|c|c|c|c|}
\hline $\begin{array}{l}\text { Nursery } \\
\text { container }^{z}\end{array}$ & $\begin{array}{l}\text { Root } \\
\text { pruningy }\end{array}$ & $\begin{array}{l}\text { \% circumference circled } \\
\text { inside position of } 57 \mathrm{~L} \\
\text { container wall }^{\mathrm{x}}\end{array}$ & $\begin{array}{l}\text { \% five largest roots }>5 \\
\text { mm diameter grew } \\
\text { into soil }{ }^{w}\end{array}$ & $\begin{array}{l}\% \text { circumference without roots } \\
>5 \mathrm{~mm} 5 \mathrm{~cm} \text { beyond position } \\
\text { of } 57 \mathrm{~L} \text { container wall }\end{array}$ \\
\hline \multirow[t]{2}{*}{ PC } & Yes & $26 c^{v}$ & $78 \mathrm{a}$ & $18 \mathrm{~d}$ \\
\hline & No & $9 \mathrm{~d}$ & $29 c$ & $65 \mathrm{a}$ \\
\hline \multirow[t]{2}{*}{ SC } & Yes & $54 \mathrm{~b}$ & $38 \mathrm{~b}$ & $27 c$ \\
\hline & No & $69 \mathrm{a}$ & $16 \mathrm{~d}$ & $57 \mathrm{~b}$ \\
\hline
\end{tabular}

${ }^{z}$ Trees grown in either porous- (PC) or solid-walled (SC) $3.8 \mathrm{~L}$ then $9.5 \mathrm{~L}$ nursery containers prior to shifting into $57 \mathrm{~L}$ solid-walled containers, then planted into landscape soil.

y Trees were root pruned by shaving away the outer 3 to $4 \mathrm{~cm}$ periphery of the $57 \mathrm{~L}$ root ball when planted into the landscape.

${ }^{x}$ Percent trunk circumference circled with roots $>5 \mathrm{~mm}$ diameter from either propagation container, 3.8 , and/or $9.5 \mathrm{~L}$ container position.

${ }^{w}$ Percent of the five largest diameter roots (diameter measured just beyond root collar) that grew beyond the periphery of the $57 \mathrm{~L}$ container position following the largest root at forks.

${ }^{v}$ Means in a column with a different letter are statistically different at $P<0.0001 ; \mathrm{n}=10$, averaged across propagation container type due to insignificant interactions.

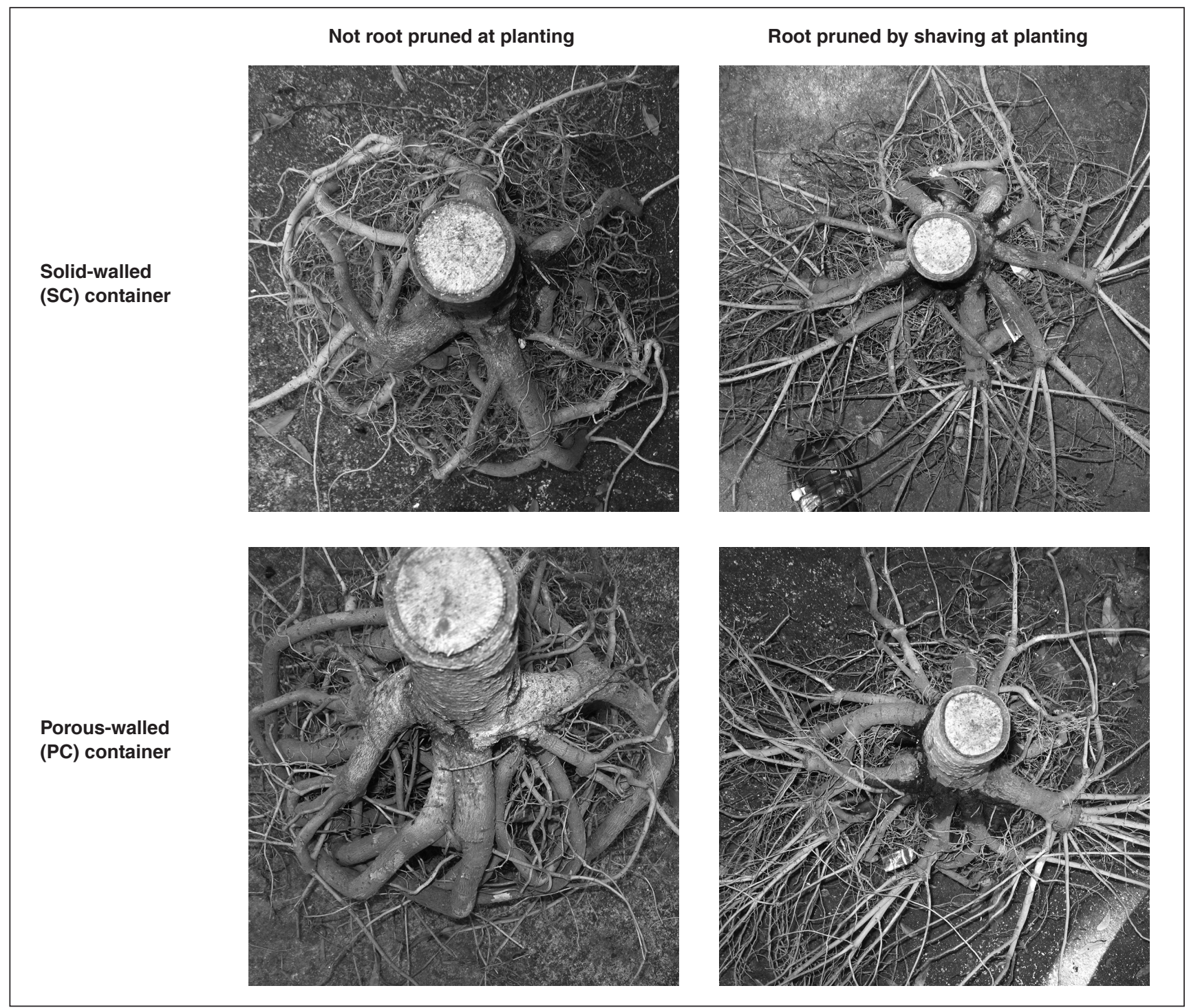

Figure 1. Four root systems from Swietenia mahogani grown in the field for eight months after planting from $57 \mathrm{~L}$ containers. Note the prominent imprint from the $57 \mathrm{~L}$ container on the root systems and vertical orientation of structural roots associated with trees planted without root pruning (left). Trees shaved at planting had little imprint, and they had a horizontal root orientation (right). Note: Trees grown in either porous- (PC) or solid-walled (SC) $3.8 \mathrm{~L}$ then $9.5 \mathrm{~L}$ nursery containers prior to shifting into $57 \mathrm{~L}$ solid-walled containers, then planted into landscape soil 
a smaller imprint, less circling, and greater number of straight radial roots growing into landscape soil (Table 4). This study could not determine which, if any, of these explanations might apply.

The deflected "cage" of roots (described in Gilman and Masters 2010) imprinted on the periphery of the non-root-pruned planted $57 \mathrm{~L}$ root balls (shown by three times the root system imprint rating, 14 times the root circling, and 16 times the number of deflected roots compared to root pruned root balls; Table 5) likely pushed laterally and downward against mineral landscape soil during winching. The stiff nature of this lignified, imprinted "cage" of roots on trees not shaved apparently resisted deformation, and therefore overturning, as did the very different architecture of the many smaller diameter roots growing straight (horizontally) into landscape soil associated with shaved trees (Figure 1). Roots that grew horizontally across the root ball/landscape soil interface on root-pruned trees may not have been stiff enough to resist bending; although there were many more of them, representing more CSA (Table 5). Sinker roots from the abundant, radially oriented horizontal roots prevalent in root pruned trees (Table 5), along with stiffer horizontal roots, would be needed to maximize anchorage (Coutts et al. 1999). In addition, winching forced horizontal roots on the winch-ward side down into decomposing nursery root ball substrate, which Gilman and Masters (2010) showed had less resistance to overturning than mineral soil. In a sense, the nonroot-pruned trees lacked straight horizontal roots, whereas shaved trees lacked the stiff "cage" of vertical roots; either combination resulted in comparable anchorage in this test of very short duration. Others showed, on much older trees, that a few large roots provided better anchorage than many smalldiameter roots (Coutts et al. 1999). This appears consistent with findings of the present study.

There is evidence that shaving root balls at planting enhances anchorage when evaluated one and two years after planting Quercus virginiana Mill. trees (Gilman and Wiese 2012; Gilman 2013). Moreover, bending stress required to tilt trees planted from containers increased with time in the first two years (Gilman and Wiese 2012), suggesting that only small treatment differences would be expected on trees planted just a few months earlier. Trees in the current study may have been winched too soon after planting to measure an effect. Swietenia mahogani should be left in the ground for a longer period in order to more thoroughly evaluate anchorage.

Similar to Swietenia mahogani planted into landscape soil from 9.5 L containers (Gilman and Harchick 2014), trunk tilt during winching to 4.1 $\mathrm{MN} / \mathrm{m}^{2}$ bending stress in the current study was correlated with several attributes of root architecture close to the trunk (Table 7). Many of these were correlated with each other, so a predictive model incorporating these would be skewed by autocorrelation. Increasing the deflected nature of the root system and reducing the number of straight roots lead to greater trunk tilting, which is supported by Ortega et al. (2006) and others. This analysis also showed that visual estimates, such as root system imprint from the container and root ball symmetry, were as good at predicting anchorage as more time-consuming measurements, such as percent trunk circled and occurrence of root systems graded as culls. These quick visual evaluations will make it relatively simple for growers, landscape architects, arborists and others to evaluate root system quality without time consuming measurements. However, low Pearson's correlation coefficients ( $\mathrm{r}=0.32$ to 0.39 ) showed that there was a substantial amount of unpredictability in bending stress, which displays a limited understanding of all factors that govern tree anchorage.

Vertical and circling roots caused by deflection in the propagation container can lead to poor rooting out, resulting in instability (Lindström et al. 2005; Chapman and Colombo 2006) and growth reductions (Krasowski 2003), but researchers did not find this when planting from much larger 9.5 L containers (Gilman and Harchick 2014) or from $57 \mathrm{~L}$ containers (current study). Perhaps the process of growing trees in these larger nursery containers forced new roots from the root collar, resulting in more growing horizontally above roots deflected by propagation containers. This would have reduced impact of vertical and circular deformations imprinted by the propagation container. This phenomenon may have gone undocumented because previous studies have been performed on trees grown in propagation containers for reforestation, not on trees transferred to a larger nursery container as in the landscape horticulture profession. 
Table 7. Correlation of root attributes ${ }^{2}$ with trunk angle and rest angle following winching seven months after planting $57 \mathrm{~L}$ containers into landscape.

\begin{tabular}{|c|c|c|}
\hline \multirow[t]{2}{*}{ Root attribute } & \multicolumn{2}{|c|}{ Pearson correlation coefficient ( $P$ value) } \\
\hline & $\begin{array}{l}\text { Trunk angle while holding } \\
\text { at } 4.1 \mathrm{MN} / \mathrm{m}^{2}\end{array}$ & $\begin{array}{l}\text { Trunk rest angle immediately } \\
\text { following winching to } 4.1 \mathrm{MN} / \mathrm{m}^{2}\end{array}$ \\
\hline $3.8 \mathrm{~L}$ visual imprint rating ${ }^{y}$ & $0.32(0.05)$ & $(>0.05)$ \\
\hline $\begin{array}{l}\text { No. radiating straight roots trunk to } 5 \mathrm{~cm} \\
\text { beyond } 57 \mathrm{~L} \text { container wall position }{ }^{\mathrm{x}}\end{array}$ & $-0.34(0.03)$ & $-0.33(0.04)$ \\
\hline Percent graded as cull ${ }^{\mathrm{w}}$ & $0.38(0.02)$ & $0.34(0.04)$ \\
\hline Root symmetry rating ${ }^{v}$ & $-0.39(0.01)$ & $-0.33(0.04)$ \\
\hline $\begin{array}{l}\text { Percent circumference without roots }>5 \mathrm{~mm} \\
\text { diameter } 5 \mathrm{~cm} \text { beyond } 57 \mathrm{~L} \text { container wall position }\end{array}$ & $0.39(0.01)$ & $(>0.05)$ \\
\hline $\begin{array}{l}\text { Total no. roots }>3 \mathrm{~mm} \text { diameter grew into landscape } \\
\text { from top half of } 57 \mathrm{~L} \text { container root ball }\end{array}$ & $-0.33(0.04)$ & $-0.38(0.02)$ \\
\hline Root CSA $\left(\mathrm{mm}^{2}\right)$ top half ${ }^{u}$ & $-0.33(0.04)$ & $-0.38(0.02)$ \\
\hline \multicolumn{3}{|c|}{$\begin{array}{l}\text { z Roots within a } 60 \mathrm{~cm} \text { diameter } 60 \mathrm{~cm} \text { deep cone shaped soil volume centered on the trunk. } \\
\text { y Visual rating of root deflection severity at indicated container position with } 1=\text { little imprint or retained "cage" formed by deflected roots, and } 5=\text { strong imprin } \\
\text { formed by deflected roots retaining the shape of the container). } \\
\text { x Number of roots }>3 \mathrm{~mm} \text { diameter measured } 5 \mathrm{~cm} \text { outside the position of the } 57 \mathrm{~L} \text { container wall that grew from trunk at }<45 \text { degree angle to substrate surface } \\
\text { without making a turn of }>60 \text { degrees relative to parent root azimuth at trunk. } \\
\text { w Graded cull according to Anonymous }(2015) \text {. } \\
{ }^{v} \text { Visual rating with } 1=\text { radially asymmetrical distribution of roots with most on one side of root ball, and } 5=\text { radially symmetrical distribution of mother roots } \\
\text { (roots growing directly from stem). } \\
\text { u Root cross-sectional area }(\mathrm{CSA}) \text { measured } 5 \mathrm{~cm} \text { outside } 57 \mathrm{~L} \text { root ball position for roots }>3 \mathrm{~mm} \text { diameter growing from top half of root ball. }\end{array}$} \\
\hline
\end{tabular}

\section{CONCLUSION}

Pruning by shaving off (also referred to as boxing, Weicherding et al. 2007) the root ball periphery when trees were planted into landscape soil from $57 \mathrm{~L}$ containers had a larger impact on root architecture than either propagation or nursery container type. Effect of propagation container on root architecture was modified by the type of nursery container used subsequently. Germinating Swietenia mahogani seeds in porouswalled propagation containers resulted in large differences in root architecture when trees were young (Gilman and Paz 2014), but some of these differences did not persist three years later once trees were planted for eight months in landscape soil. Growing in a nursery container with extremely porous walls resulted in root systems dominated by horizontal and descending roots; those in solid-walled containers were dominated by vertical and deflected roots.

Acknowledgments. Thanks to the Horticulture Research Institute, GreatSouthernTreeConference.org (which included funding from the container manufacturers of the tested containers), and Quintessence Nursery, Loxahatchee, Florida, U.S., for partial support of this study.

\section{LITERATURE CITED}

Amoroso, G., P. Frangi, R. Piatti, F. Ferrini, A. Fini, and M. Faoro. 2010. Effect of container design on plant growth and root deformation of littleleaf linden and field elm. HortScience 45:18291829.

Anonymous. 2009. Specification Guidelines for Container-grown Trees in California. Urban Tree Foundation, Visalia, California, U.S.

Anonymous. 2014. American Standard for Nursery Stock. American Nursery Association, Washington, D.C., U.S.

Anonymous. 2015. Florida Grades and Standards for Nursery Plants. Florida Department of Agriculture and Consumer Services, Gainesville, Florida, U.S.

Arnold, M.A., and E. Young. 1991. $\mathrm{CuCo}_{3}$-painted containers and root pruning affect apple and green ash root growth and cytokinin levels. HortScience 26:242-244.

Balisky, A.C., P. Salonius, C. Walli, and D. Brinkman. 1995. Seedling roots and forest floor: Misplaced and neglected aspects of British Columbia’s reforestation effort. Forestry Chronicle 71:59-65.

Burdett, A.N., H. Coates, R. Eremko, and P.A.F. Martin. 1986. Toppling in British Columbia’s lodgepole pine plantations: Significance, cause, and prevention. Forestry Chronicle 62:433-439.

Chapman, K.A., and S.J. Colombo. 2006. Early root morphology of jack pine seedlings grown in different types of containers. Scandinavian Journal of Forest Research 21:372-379.

Chavasse, C.G.R. 1978. The root form and stability of planted trees, with special reference to nursery and establishment practice. pp. 54-64. In: E. Van Eerden and J.M. Kinghorn (Eds.). Proceedings of the Root Form of Planted Trees Symposium British Columbia Ministry of Forests/Canadian Forest Service Joint Report No. 8. 
Coutts, M.P., C. Walker, and A.C. Burnand. 1990. Effects of establishment method on root form of lodgepole pine and Sitka spruce and on the production of adventitious roots. Forestry 63:143-159.

Coutts, M.P., C.C.N. Nielson, and B.C. Nicoll. 1999. The development of symmetry, rigidity, and anchorage in the structural root system of conifers. Plant and Soil 217:1-15.

Danjon F., T. Fourcaud, and D. Bert. 2005. Root architecture and wind-firmness of mature Pinus pinaster. New Phytology $168: 387-400$

Davis, S., and D.F. Jacobs. 2004. Quantifying root system quality of nursery seedlings and relationship to outplanting performance. New Forests 30:295-311.

Dumroese, R.K., and D.L. Wenny. 1997. An assessment of ponderosa pine seedlings grown in copper-coated polybags. Tree Planters' Notes 48:60-64.

Fourcaud, T., J. Ji, Z. Zhang, and A. Stokes. 2007. Understanding the impact of root morphology on overturning mechanisms: A modeling approach. Annals of Botany 100:1093.

Gilman, E.F. 2013. Anchorage influenced by production method and root pruning. Arboriculture \& Urban Forestry 39:1-5.

Gilman, E.F., and C. Harchick. 2014. Root system morphology influences lateral stability of Swietenia mahogani. Arboriculture \& Urban Forestry 40:27-35.

Gilman, E.F., and C. Wiese. 2012. Root pruning at planting and planting depth in the nursery impact root system morphology and anchorage. Arboriculture \& Urban Forestry 38:232-239.

Gilman, E.F., and F. Masters. 2010. Effect of tree size, root pruning and production method on root growth and lateral stability of Quercus virginiana. Arboriculture \& Urban Forestry 36:281-291.

Gilman, E.F., and M. Paz. 2014. Root system morphology influenced by container design, retention time, and root pruning. Arboriculture \& Urban Forestry 40:16-26.

Gilman, E.F., and R.C. Beeson, Jr. 1995. Copper hydroxide affects root distribution of Ilex cassine in plastic containers. HortTechnology 5:48-49.

Gilman, E.F., M. Paz, and C. Harchick. 2015. Effect of eight container types and root pruning during nursery production on root architecture of Acer rubrum. Arboriculture \& Urban Forestry in press.

Graham, B.F., and F.H. Bormann. 1966. Natural root grafts. Botanical Reviews 32:255-292.

Hay, R.L., and F.W. Woods. 1968. Distribution of available carbohydrates in planed loblolly pine root systems. Forest Science 14:301-303.

Hay, R.L., and F.W. Woods. 1978. Carbohydrate relationships in root systems of planted loblolly pine seedlings. pp. 73-84. In: E. Van Eerden and J.M. Kinghorn (Eds.). Proceedings of the root form of planted trees symposium. British Columbia Ministry of Forests/Canadian Forest Service Joint Report 8.

Hewitt, A., and G. Watson. 2009. Bare root liner production can alter tree root architecture. Arboriculture \& Urban Forestry 27:99-104

Krasowski, M.J. 2003. Root system modifications by nursery culture reflect on post-planting growth and development of coniferous seedlings. Forest Chronicle 79:882-891.

Krasowski, M.J., and J.N. Owens. 2000. Morphological and physical attributes of root systems and seedlings growth in three different Picea glauca reforestation stock. Canadian Journal of Forest Research 30:1669-1681.
Lindström, A., and G. Rune. 1999. Root deformation in plantations of container-grown Scots pine trees: Effects on root growth, tree stability and stem straightness. Plant and Soil 217:29-37.

Lindström, A., C. Hellqvist, and E. Stattin. 2005. Mini seedlings: A new forest regeneration system. pp. 56-58. In: The Thin Green Line: A symposium on the state-of-the-art in reforestation. Ontario Forest Research Institute, Ontario Ministry of Natural Resources, 1235 Queen Street East Sault Ste. Marie, Ontario, Canada P6A 2E5.

Lyford, W.H. 1980. Development of the root system of northern red oak (Quercus rubra L.). Harvard Forest Paper 21, Harvard University.

Marshall, M.D., and E.F. Gilman. 1998. Effects of nursery container type on root growth and landscape establishment of Acer rubrum L. Journal of Environmental Horticulture 16:55-59.

Neal, C. 2009. Production systems for small trees and shrubs in New Hampshire. In: G.W. Watson, B. Scharenbroch, L. Costello, and E.F. Gilman (Eds.). Landscape Below Ground III. Morton Arboretum, October 2008. International Society of Arboriculture, Champaign, Illinois, U.S.

Ortega, U., J. Majada, A. Mena-Petite, J. Sanchez-Zabala, N. Rodriguez-Itturrizar, K. Txarterina, J. Azpitarte, and M. Duñabeitia. 2006. Field performance of Pinus radiata D. Don produced in nursery with different types of containers. New Forests 31:97-112.

Owen, J., and H. Stoven. 2008. Searching for the perfect pot. Digger, March, Oregon Association Nursery. Wilsonville, Oregon, U.S.

Rune, G. 2003. Slits in container wall improve root structure and stem straightness of outplanted Scots pine seedlings. Silva Fenn $37: 333-342$.

Salonius, P., K. Beaton, and B. Roze. 2000. Effects of cell size and spacing on root density and field performance of containerreared black spruce. Information Report M-X-208E, Canadian Forest Service, Atlantic Forestry Centre, Frederickton, New Brunswick, Canada.

Stoven O'Connor, A., J.E. Klett, and A.J. Koski. 2013. Container type and overwintering treatments affect substrate temperature and growth of chanticleer ${ }^{\circ}$ pear (Pyrus calleryana 'Glen's Form') in the Nursery. Journal of Environmental Horticulture 31:117-123.

Watson, G.W., and G. Kupkowski. 1991. Effects of a deep layer of mulch on the soil environment and tree root growth. Journal of Arboriculture 17:242-245.

Watson, G.W., and T.D. Sydnor. 1987. The effect of root pruning on the root system of nursery trees. Journal of Arboriculture $13: 126-130$.

Weicherding, P.J., C.P. Giblin, J.H. Gillman, D.L. Hanson, and G. Johnson. 2007. Mechanical root-disruption practices and their effect on circling roots of pot-bound Tilia cordata Mill. and Salix alba L. 'Niobe'. Arboriculture \& Urban Forestry 33:43-47.

Wenny, D.L., and R.L. Woollen. 1989. Chemical root pruning improves the root system morphology of containerized seedlings. Western Journal of Applied Forestry 4:15-17.

Wenny, D.L., Y. Liu, R.K. Dumroese, and H.L. Osborne. 1988. First year field growth of chemically root pruned containerized seedlings. New Forests 2:111-118.

Whitcomb, C.E., and J.D. Williams. 1985. Stair-step container for improved root growth. HortScience 20:66-67. 


\section{Edward F. Gilman (corresponding author) \\ Professor}

Environmental Horticulture Department

University of Florida

Gainesville, Florida, U.S.

egilman@ufl.edu

Maria Paz

Biologist

Environmental Horticulture Department

University of Florida

Gainesville, Florida, U.S.

Chris Harchick

Farm Manager

Environmental Horticulture Department

University of Florida

Gainesville, Florida, U.S.

Résumé. La capacité de l’Acajou des Antilles (Swietenia mahogani L.) à s'ancrer après plantation dans des contenants de pépinière de 9,5 L a été attribuée à l'architecture des racines à l'intérieur de la motte racinaire initiale. Les objectifs de cette étude étaient d'évaluer l'architecture des racines, leur croissance, et l'ancrage au sol d'arbres plantés provenant de contenants de $57 \mathrm{~L}$. Le diamètre du tronc et la hauteur des arbres, en pépinière et après leur plantation dans des aménagements, nont pas été affectés par le mode de propagation, ni par le type de contenant de croissance en pépinière et ni par l'élagage des racines au moment de la plantation. Les arbres cultivés dans des contenants à parois rigides durant toute la période passée en pépinière montraient les plus grandes déficiences racinaires. Contrairement aux contenants de propagation, la porosité des parois des plus grands contenants utilisés en pépinière a affecté l'architecture racinaire jusqu'à huit mois après leur plantation définitive. Un contenant de pépinière à parois poreuses produit un système racinaire avec moins de racines encerclantes, davantage de racines latérales horizontales et un diamètre plus important pour les racines franchissant l'interface entre le substrat du contenant et le sol environnant la fosse de plantation, qu'un contenant à parois rigides. Lélagage des racines a augmenté la symétrie du système racinaire tout en réduisant l'impact des déviations racinaires observés avec les contenants de $57 \mathrm{~L}$. Malgré l'amélioration de l'architecture racinaire, il n'y a eu aucune incidence d'aucun traitement sur l'ancrage des arbres(inclinaison du tronc pendant le treuillage ou angle de repos après le treuillage) huit mois après la plantation, peut-être en raison de la courte durée de l'étude.

Zusammenfassung. Die Fähigkeit von Swietenia mahogani L. sich nach der Pflanzung in 9,5 Liter Containern zu verankern, wird der Wurzelarchitektur in dem original gepflanzten Wurzelballen zugeschrieben. Die Ziele dieser Studie waren die Bewertung der Wurzelarchitektur, des Wachstums und der Verankerung von Bäumen aus 57 Liter Containern. Stammdurchmesser und Baumhöhe in der Baumschule und nach der Pflanzung in die Landschaft waren unbeeinflusst durch die Propagation oder den Pflanzcontainertyp oder den Wurzelrückschnitt bei der Pflanzung. Bäume, die während der ganzen Zeit in der Baumschule in Containern mit soliden Wänden standen, hatten die größten Wurzeldefekte. Anders als die Aufzuchtcontainer beeinflusste die Wandporosität der größeren Container die Wurzeln acht Monate nach der Verpflanzung in die Landschaft. Ein Pflanzcontainer mit porösen Wänden produziert ein Wurzelsystem mit weniger Ringwurzeln, mehr horizontalen (geraden) lateralen Wurzeln und einem größeren Wurzelquerschnitt, der den Übergang des Balles vom Container zur Pflanz- grube überbrückt im Gegensatz zu einem mit soliden Wänden. Ein Wurzelrückschnitt verstärkte die Wurzelsystemsymmetrie während die sichtbare Bewertung der Wurzelbiegung durch den Container im 57 Liter Container reduziert wurde. Ungeachtet der verbesserten Wurzelarchitektur gab es keinen Einfluss von irgendeiner Behandlung auf die Verankerung (Stamm versagte während des Zugversuchs oder blieb anschließend schief) in den acht Monaten nach der Pflanzung, was möglicherweise an der kurzen Dauer des Versuchs lag.

Resumen. Se ha atribuido la habilidad de Swietenia mahogani L. para anclar después de la plantación en contenedores de vivero de $9.5 \mathrm{~L}$ a la arquitectura de la raíz dentro de la bola original plantada. Los objetivos de este estudio fueron evaluar la arquitectura de la raíz, el crecimiento y el anclaje en los árboles plantados de contenedores de $57 \mathrm{~L}$. El diámetro del tronco y la altura del árbol en el vivero y después de la plantación en el paisaje no se vieron afectados por la propagación o tipo de contenedor o la poda de raíces durante la plantación. Los árboles crecidos en recipientes de paredes sólidas en cada etapa en el vivero tuvieron los mayores defectos de la raíz. En contraste, la porosidad de la pared de los contenedores más grandes impactó la arquitectura de las raíces ocho meses después de la plantación en el paisaje. Un contenedor de vivero con paredes porosas produce un sistema radicular con menos raíces circulares, raíces laterales más horizontales (rectas), y una mayor área radicular transversal, uniendo la interfase sustrato/suelo del paisaje, que uno con pared sólida. La poda de las raíces aumentó la simetría del sistema de raíces al tiempo que redujo la calificación visual para la desviación de la raíz por el contenedor de $57 \mathrm{~L}$. A pesar de la mejora de la arquitectura de la raíz, no hubo un impacto de cualquier tratamiento de anclaje (la inclinación del tronco durante o después la instalación) ocho meses después de la plantación, tal vez debido a la corta duración del estudio. 